\title{
Office of Research Services
}

National Cancer Institute

\section{Source}

National Cancer Institute. Office of Research Services. NCI Thesaurus. Code C82630.

An office of the National Institutes of Health $(\mathrm{NIH})$ that plans and directs service programs for public safety and security operations, scientific and regulatory support programs, and a wide variety of other program and employee services. It advises the NIH Deputy Director for Management and delivery of technical and administrative services in support of the $\mathrm{NIH}$ research mission. 